\title{
Margaret McCartney: Drugs with anticholinergic side effects and cognitive decline-cause or effect?
}

\author{
Margaret McCartney general practitioner, Glasgow
}

What happens when repeated studies find the same associations but we have no randomised controlled trials (RCTs) to say anything about causation? Several studies have found that prescribing cumulative amounts of drugs with anticholinergic side effects is associated with more cognitive decline or earlier death or both, ${ }^{1-4}$ as well as falls ${ }^{5}$ and admission to hospital with confusion and dementia. ${ }^{6}$

The daggers are pointing in the same direction. Loperamide, loratadine, baclofen, amitriptyline, oxybutynin, and chlorphenamine all have considerable anticholinergic effects and are in common use. The burden in terms of absolute risk for adverse outcomes may seem small-a difference of one or two percentage points in some studies ${ }^{7}$ but as high as 10 percentage points in others. ${ }^{4}$

But is this cause, or is it effect? Are people who are at greater risk of cognitive decline also at greater risk of symptoms that result in anticholinergic prescriptions? I expect to see a field full of unicorns before an RCT is done to definitively clear this up for ethical and practical reasons.

A French prospective trial, however, has found that stopping anticholinergic drugs tended to be associated with a reverse in cognitive decline, suggesting causality. ${ }^{8}$ But a single blind RCT in Norway found no improvements in cognitive function eight weeks after reducing anticholinergic drugs in patients at nursing homes. ${ }^{9}$ And a systematic review has concluded that "very little rigorous research has been conducted on reducing unnecessary medications in frail older adults or patients approaching the end of life." 10

So, what do we do? Some precautionary deprescribing is quite easy-such as drugs being taken but then not needed on reflection or over time, or the unholy trinity of diuretics, angiotensin converting enzyme inhibitors, and non-steroidal anti-inflammatory drugs.

Far harder is trying to balance the useful effect of nightly amitriptyline on pain, or of oxybutynin on bladder symptoms, against quality of life and future risk. Suggesting stopping drugs that offer benefit now against possible side effects later is like taking away your slice of cake and promising the possibility of a whole one in a couple of years.
I want to review drugs in the comfort of a trial so that I know what I am doing right, what I am doing wrong, and if there's anything else I should know about. The art of medicine involves handling uncertainty and helping to decide what is important to patients and families, while being as safe as possible and also taking some gambles.

Some uncertainties can be reduced, but not all. Multimorbidity, polypharmacy, and complexity have been the NHS's bread and butter for the past decade and more, but we still lack sufficient evidence, resources, and tools to deal with these well.

I can't see patient charities or pressure groups demanding better care for people with early multimorbidity who are taking eight drugs a day, already caring for a relative, and trying to handle debts and unemployment. If ever GPs had to advocate for better data, it's surely here. At the very least, we need rapid help with RCTs on the effects of stopping drugs.

Follow Margaret on Twitter, @mgtmccartney

Competing interests: I have read and understood the BMJ policy on declaration of interests and declare the following interests: I'm an NHS GP partner, with income partly dependent on Quality and Outcomes Framework points. I'm a part time undergraduate tutor at the University of Glasgow. I've written two books and earn from broadcast and written freelance journalism. I'm an unpaid patron of Healthwatch. I make a monthly donation to Keep Our NHS Public. I'm a member of Medact. I'm occasionally paid for time, travel, and accommodation to give talks or have locum fees paid to allow me to give talks but never for any drug or public relations company. I was elected to the national council of the Royal College of General Practitioners in 2013 and am chair of its standing group on overdiagnosis. I have invested a small amount of money in a social enterprise, Who Made Your Pants?

The $B M J$ s readers can buy Margaret's new book, Living with Dying, for $£ 7.99$ (RRP £11.99) including UK delivery from www.pinterandmartin. com with checkout code BMJ799.

Provenance and peer review: Commissioned; not externally peer reviewed.

Fox C, Richardson K, Maidment ID, et al. Anticholinergic medication use and cognitive impairment in the older population: the Medical Research Council Cognitive Function and Ageing Study. J Am Geriatr Soc 2011;59:1477-83. 
2 Han L, Agostini JV, Allore HG. Cumulative anticholinergic exposure is associated with poor memory and executive function in older men. J Am Geriatr Soc 2008;56:2203-10. Myint PK, Fox C, Kwok CS, Luben RN, Wareham NJ, Khaw KT. Total anticholinergic burden and risk of mortality and cardiovascular disease over 10 years in 21636 middle aged and older men and women of EPIC-Norfolk prospective population study. Age Ageing 2015;44:219-25.

4 Gray SL, Anderson ML, Dublin S, et al. Cumulative use of strong anticholinergics and incident dementia: a prospective cohort study. JAMA Intern Med 2015;175:401-7.

5 Nishtala PS, Narayan DW, Wang T, Hilmer SN. Association of drug burden index with falls, general practitioner visits, and mortality in older people. Pharmacoepidemiol Drug Saf 2014;23:753-8.

6 Kalisch Ellett LM, Pratt NL, Ramsay EN, Barratt JD, Roughead EE. Multiple medication use and risk of hospital admission for confusion or dementia. J Am Geriatr Soc 2014;62:1916-22.
7 Kumpula E, Bell JS, Soini H, Pitkälä KH. Anticholinergic drug use and mortality among residents of long term care facilities: a prospective cohort study. J Clin Pharmacol 2011;51:256-63.

8 Carrière I, Fourrier-Reglat A, Dartigues J, et al. Drugs with anticholinergic properties, cognitive decline, and dementia in the elderly general population: the 3-city study. Arch Intern Med 2009;169:1317-24.

9 Kersten H, Molden E, Tolo IK, Skovlund E, Engedal K, Wyller TB. Cognitive effects of reducing anticholinergic drug burden in a frail elderly population a randomised controlled trial. J Gerontol A Biol Sci Med Sci 2013;68:271-8.

10 Tjia J, Velten SJ, Parsons C, Valluri S, Briesacher BA. Studies to reduce unnecessary medication use in frail older adults: a systematic review. Drugs Aging 2013;30:285-307.

Cite this as: BMJ 2015;350:h1428

(c) BMJ Publishing Group Ltd 2015 